\title{
An investigation into the reactions of biochar in soil
}

\author{
S. D. Joseph ${ }^{\mathrm{A}, \mathrm{K}}$, M. Camps-Arbestain ${ }^{\mathrm{B}}$, Y. Lin $^{\mathrm{A}}$, P. Munroe ${ }^{\mathrm{A}}$, C. H. Chia ${ }^{\mathrm{A}}$, J. Hook ${ }^{\mathrm{C}}$, \\ L. van Zwieten ${ }^{\mathrm{D}}$, S. Kimber ${ }^{\mathrm{D}}$, A. Cowie ${ }^{\mathrm{E}}$, B. P. Singh ${ }^{\mathrm{F}}$, J. Lehmann ${ }^{\mathrm{G}}$, N. Foidl ${ }^{\mathrm{H}}$, \\ R. J. Smernik', and J. E. Amonette

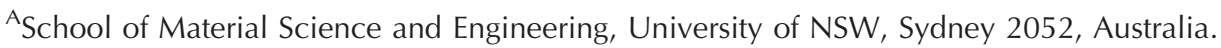 \\ ${ }^{B}$ New Zealand Biochar Research Centre, Private Bag 11222, Massey University, 4442 Palmerston North, \\ New Zealand. \\ CNMR Facility, Analytical Centre, University of NSW, Sydney, NSW 2052, Australia. \\ D Industry and Investment NSW, Wollongbar, NSW 2477, Australia. \\ ${ }^{E}$ National Centre for Rural Greenhouse Gas Research, University of New England, Armidale, \\ NSW 2351, Australia. \\ FForest Science Centre, Industry and Investment NSW, PO Box 100, Beecroft, NSW 2119, Australia. \\ GDepartment of Crop and Soil Sciences, College of Agriculture and Life Sciences, Cornell University, \\ Ithaca, NY 14853, USA. \\ ${ }^{H}$ Venearth LLC, San Francisco, USA. \\ 'School of Agriculture, Food and Wine, DP 636, The University of Adelaide, Adelaide, SA 5000, Australia. \\ JPacific Northwest National Laboratory, Richland, WA 99354, USA. \\ ${ }^{\mathrm{K}}$ Corresponding author. Email: joey.stephen@gmail.com
}

\begin{abstract}
Interactions between biochar, soil, microbes, and plant roots may occur within a short period of time after application to the soil. The extent, rates, and implications of these interactions, however, are far from understood. This review describes the properties of biochars and suggests possible reactions that may occur after the addition of biochars to soil. These include dissolution-precipitation, adsorption-desorption, acid-base, and redox reactions. Attention is given to reactions occurring within pores, and to interactions with roots, microorganisms, and soil fauna. Examination of biochars (from chicken litter, greenwaste, and paper mill sludges) weathered for 1 and 2 years in an Australian Ferrosol provides evidence for some of the mechanisms described in this review and offers an insight to reactions at a molecular scale. These interactions are biochar- and site-specific. Therefore, suitable experimental trials - combining biochar types and different pedoclimatic conditions - are needed to determine the extent to which these reactions influence the potential of biochar as a soil amendment and tool for carbon sequestration.
\end{abstract}

Additional keywords: surface charge, pyrolysis, redox, soil amendment, soil carbon, carbon sequestration, soil organic matter, biochar-soil mineral.

\section{Introduction}

Biochar is a carbon-rich solid material produced by heating biomass in an oxygen-limited environment and is intended to be added to soils as a means to sequester carbon (C) and maintain or improve soil functions. Interactions between biochar, soil, microbes, and plant roots are known to occur within a short period of time after application to the soil (Lehmann and Joseph 2009). However, the extent, rates, and implications of these interactions are still far from being understood, and this knowledge is needed for an effective evaluation of the use of biochar as a soil amendment and tool for $\mathrm{C}$ sequestration. Recent studies (Steiner et al. 2007; Bruun et al. 2008; Singh and Cowie 2008; Kuzyakov et al. 2009) suggest that the types and rates of interactions (e.g. adsorption-desorption, precipitation-dissolution, redox reactions) that take place in the soil depend on the following factors: ( $i$ ) feedstock composition, in particular the total percentage and specific composition of the mineral fraction; (ii) pyrolysis process conditions; (iii) biochar particle size and delivery system; and (iv) soil properties and local environmental conditions.

High-temperature pyrolysis $\left(>550^{\circ} \mathrm{C}\right)$ produces biochars that generally have high surface areas $\left(>400 \mathrm{~m}^{2} / \mathrm{g}\right.$ ) (Downie et al. 2009; Keiluweit et al. 2010), are highly aromatic and therefore very recalcitrant to decomposition (Singh and Cowie 2008), and are good adsorbents (Mizuta et al. 2004; Lima and Marshall 2005). Low-temperature pyrolysis $\left(<550^{\circ} \mathrm{C}\right)$, on the other hand, favours greater recovery of $\mathrm{C}$ and also of several nutrients (e.g. N, K, and S) that are increasingly lost at higher temperatures (Keiluweit et al. 2010). Low-temperature biochars, which have a less-condensed $\mathrm{C}$ structure, are expected to have a greater reactivity in soils than higher temperature biochars and a better contribution to soil fertility (Steinbeiss et al. 2009). In fact, pot and field trials indicate that high mineral-ash biochars produced at temperatures $<500^{\circ} \mathrm{C}$ have, in some cases, given 
higher crop yields than more recalcitrant biochars produced at higher temperatures (Chan et al. 2008). Based on this greater reactivity, low-temperature biochars have been blended with minerals and sludges to balance the nutrient content of the amendments, and results of pot and field trials are now entering the scientific literature (Chia et al. 2010). However, optimal heating rates and soaking times must be determined when operating kilns at temperatures of $180-350^{\circ} \mathrm{C}$, and then adopted during production, to avoid the production of compounds that, in sufficiently high concentration, could be toxic to plants, such as acid aldehydes or phenols (Bridgwater and Boocock 2006).

This paper reviews current understanding of the reaction of biochars in soil and reports recent findings from field trials in which biochar has been in the soil (Australian Ferrosol) for 1-2 years. As biochar-soil interactions are expected to be more intense for low-temperature biochars, this work focuses on them; however, some aspects are applicable to other biochars.

\section{Properties of biochars}

Biochars produced at temperatures $<550{ }^{\circ} \mathrm{C}$, and especially those with high ash content, have intricate surface and internal properties that result in complex interactions with the components of soil (Shinogi et al. 2003; Amonette and Joseph 2009). Low-temperature biochars have a predominantly amorphous $\mathrm{C}$ structure, with a lower aromaticity than hightemperature biochars (McBeath and Smernik 2009; Keiluweit et al. 2010). The morphology of the biochar resembles that of the parent material; for example, wood biochar has the exoskeleton of the tracheids, whereas chicken manure biochar has a heterogeneous structure consisting of charred remnants of seeds, hair, proteins, digested food, bedding material, and minerals. The pore structure, size distribution, volume, and total surface area are a function of the properties of the original biomass feedstock, as well as the process conditions (Downie et al. 2009; Keiluweit et al. 2010). Most of the physical, electrical, and chemical properties change as final heat treatment temperature and time increase until a point is reached where most of the carbon is in the form of graphite (Antal and Grønli 2003). As the heat treatment temperature increases, some metals in the carbon lattice can be volatilised (e.g. $\mathrm{K}$ initiated at $\sim 400^{\circ} \mathrm{C}$ ) and the ash phases change their morphology (either transform from a crystalline structure to an amorphous structure or vice versa, e.g. silica) or chemical composition through decomposition, oxidation, or reduction (Wornat et al. 1995; Bridgwater and Boocock 2006).

The $\mathrm{pH}$ and electrical conductivity of the biochar depend on both the content and composition of the mineral fraction (also referred to as the ash fraction), and this in turn depends on the type of feedstock and process conditions under which the biochar is produced (Chan and Xu 2009; Singh et al. 2010). The nutrient content of biochars is also largely influenced by the type of feedstock and pyrolysis conditions (Singh et al. 2010), whereas the availability of nutrients in biochars is related to the type of bonds associated with the element involved (De Luca et al. 2009; Yao et al. 2010). Phosphorus is mainly found in the ash fraction, with $\mathrm{pH}$-dependent reactions and presence of chelating substances controlling its solubilisation (De Luca et al.
2009). Potassium in biochar is generally available to plants (Amonette and Joseph 2009). Conversely, nitrogen availability from biochars has been shown to vary widely depending on final temperature of pyrolysis, heating rate, time of holding at final temperature, and type of feedstock (Amonette and Joseph 2009). While some researchers have indicated a low $\mathrm{N}$ availability (Gaskin et al. 2008; Yao et al. 2010) and suggested that $\mathrm{N}$ is mostly present as heterocyclic N (so-called 'black N'; Knicker et al. 1996), others have observed considerable $\mathrm{N}$ availability from chicken litter biochars (Chan et al. 2008), where it is mainly found as nitrate on the surface of the biochars.

The mineral components that exist within the $\mathrm{C}$ structure of the biochar differ in the range of structural ordering (Yao et al. 2010) and in electrical and magnetic properties. Ishihara (1996) reported that wood charcoal carbonised at $<300^{\circ} \mathrm{C}, 300-800^{\circ} \mathrm{C}$, and $>800^{\circ} \mathrm{C}$ acts as an insulator, a semiconductor, and a conductor, respectively. The interfaces between the mineral phase and the amorphous $\mathrm{C}$ can have a high defect structure, including nanoscale pores (Fig. 1), where reactions can occur preferentially. The high reactivity of the surfaces of biochar particles in soils is partly attributed to the presence of a range of reactive functional groups, some of which are $\mathrm{pH}$-dependent (Cohen-Ofri et al. 2007; Cheng et al. 2008; Amonette and Joseph 2009; Cheng and Lehmann 2009; Keiluweit et al. 2010).

\section{Methods of storage and incorporation}

The initial weathering of biochar particles may occur during storage, should the biochar come in contact with moist air (Boehm 2001). This phenomenon, known as 'ageing', occurs

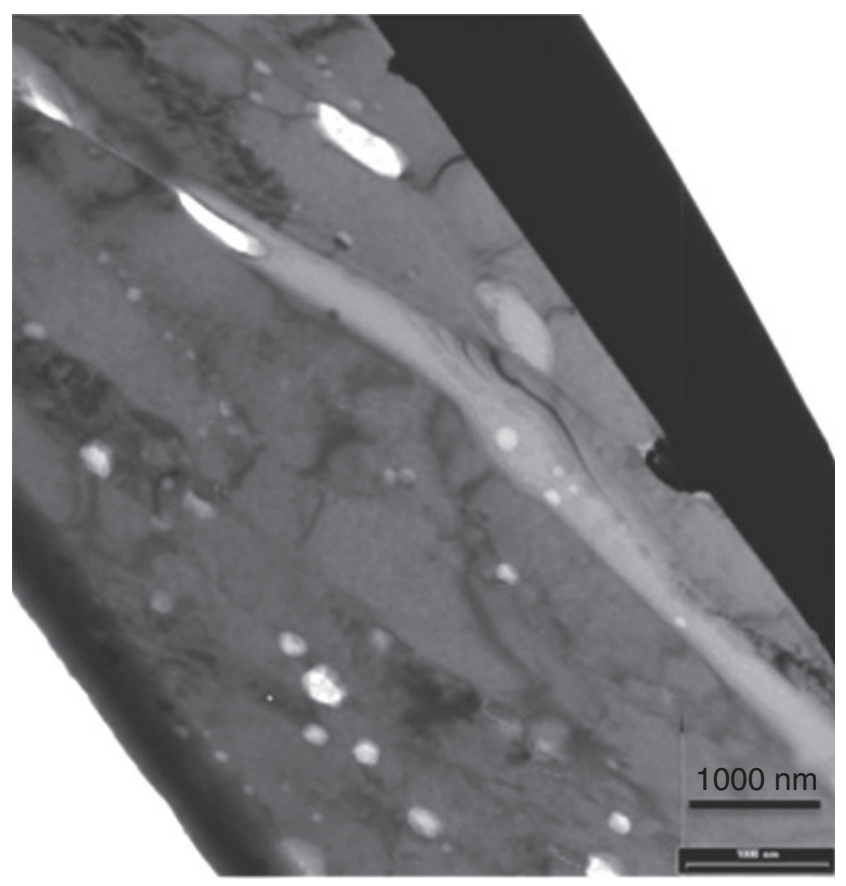

Fig. 1. Bright field TEM image of a chicken manure biochar produced at $350^{\circ} \mathrm{C}$. The lighter grey phase is amorphous carbon; the small white areas are pores; the dark phase is calcium carbonate. The carbonate phase contains low angle grain boundaries that consist of walls of dislocations. (Source: biochar from Cornell University; picture from EMU UNSW.) 
as a result of the oxidation of exposed $\mathrm{C}$ rings with a high density of $\pi$-electrons (Contescu et al. 1998) and free radicals (MontesMorán et al. 2004). If biochar is mixed with decomposable organic material, such as compost, weathering reactions (e.g. C oxidation, dissolution of mineral components) during storage are enhanced (Yoshizawa et al. 2007; Dias et al. 2010).

The method for biochar incorporation into the soil may potentially modify the structure and the particle size of biochar, and this may affect the mineralisation rate, as seen for wildfire charcoal (Nocentini et al. 2010), and the waterholding capacity. Ploughing results in greater soil mechanical disturbance than other methods, such as deep banding or direct drilling. Mechanical disturbance of soils amended with biochar has been shown to promote biochar decomposition for several weeks following disruption (Kuzyakov et al. 2009). Those authors suggested that the destruction of aggregates and exposure of native organic matter to microbial attack facilitated the co-metabolic decomposition of biochar. Most of the common methods used to date (spreading and incorporation with rotary plough, deep banding) involve the incorporation of large volumes of biochar $(>5 \mathrm{t} / \mathrm{ha})$ into the soil to a depth of 60-100 mm (Blackwell et al. 2009; Major et al. 2009a).

\section{Initial reactions of biochar when placed in the soil}

\section{Overview}

Little research has been undertaken to determine biochar weathering and reactions that occur within the first few weeks after application of biochar to soils (Singh and Cowie 2008; Kuzyakov et al. 2009). The ageing of biochar, which might have started before its addition to soil, continues once it is incorporated in the soil, at a rate that is partly governed by conditions of moisture (Nguyen and Lehmann 2009) and temperature (Cheng and Lehmann 2009; Nguyen and Lehmann 2009). An immediate evolution of biochar-derived $\mathrm{CO}_{2}$ from soils has been observed within the first 2 weeks (Singh and Cowie 2008; Hilscher et al. 2009; Kuzyakov et al. 2009) after amendment and tends to decrease exponentially with time (Singh and Cowie 2008; Kuzyakov et al. 2009). As with mineral weathering, the presence of water will have a major role in processes such as dissolution, hydrolysis, carbonation and decarbonation, hydration, and redox reactions, affecting biochar weathering in soil, as well as interactions with soil biota. The rates at which these reactions occur depend on the nature of the reactions, type of biochar, and pedoclimatic conditions. These reactions are discussed below.

\section{Dissolution-precipitation reactions}

The dissolution and leaching of soluble salts and organic compounds present in the biochar will be among the first reactions, especially if soils are moist and there is a rain event (Shinogi et al. 2003; Major et al. 2009b). The initial dissolution of soluble salts (e.g. $\mathrm{K}$ and $\mathrm{Na}$ carbonates and oxides) may produce a $\mathrm{pH}$ increase in the water-film around the biochar particles. However, in leaching environments, the $\mathrm{pH}$ will tend to decrease as these salts are lost from the system (Yao et al. 2010); the magnitude of this decrease is determined by the intensity of the leaching and the acid-buffering capacity of the system. The $\mathrm{pH}$ around biochar particles would also initially increase due to the Lewis basicity of $\pi$-electrons (Contescu et al. 1998) and then decrease as acidic functional groups are formed on biochar surfaces (Cheng et al. 2006; Cheng and Lehmann 2009). In high-ash biochars, the $\mathrm{pH}$ increase due to basic salts may be larger than the $\mathrm{pH}$ decrease induced by surface oxidation even over longer time scales (Nguyen and Lehmann 2009).

Over time, some organic compounds present in the biochar can be released to solution; for example, a range of biopolymers and low molecular weight compounds have been detected in the leachates of an Acacia saligna biochar (produced at $400^{\circ} \mathrm{C}$ with a heat treatment time of $30 \mathrm{~min}$ ) and a biochar-mineral complex produced at low temperature (Henderson, unpubl. data; Fig. 2). The amount and type of organic compounds released are highly dependent on biochar characteristics and environmental conditions. Hockaday (2006) and Hockaday et al. (2007) detected condensed aromatic ring structures in the pore water of soils on which charcoal was deposited 100 years before,

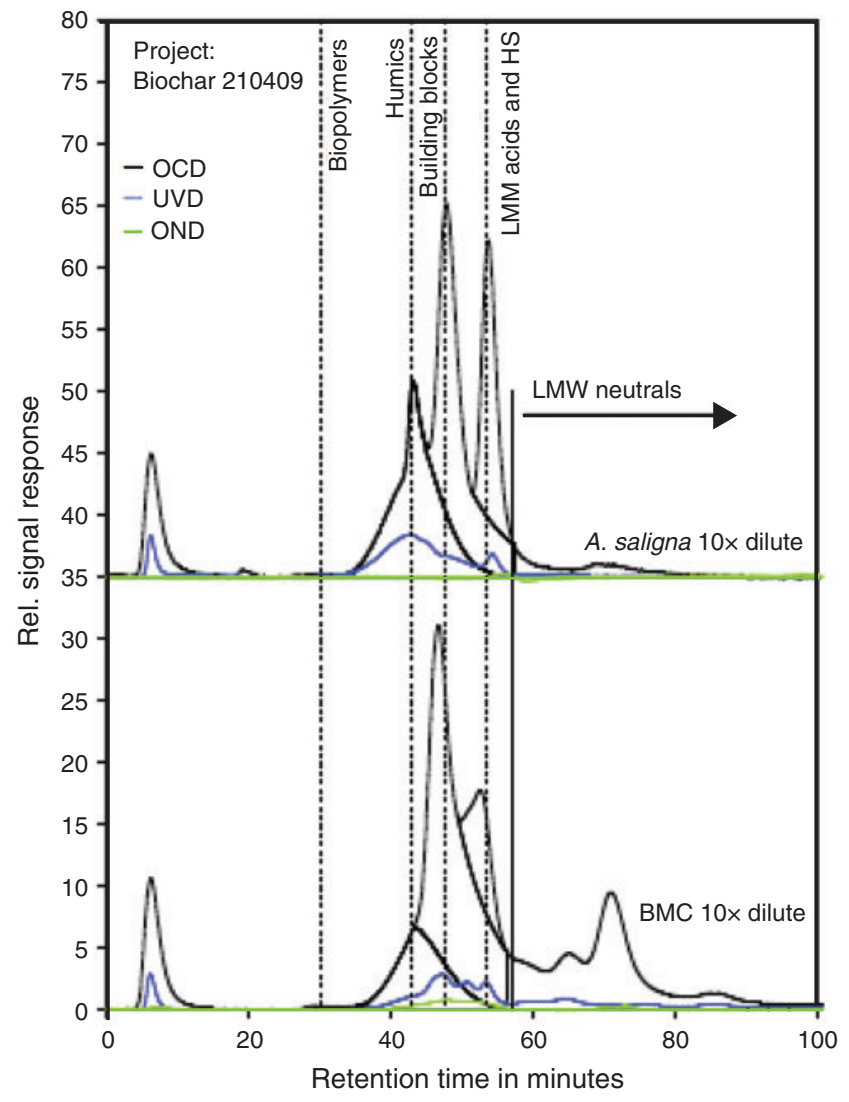

Fig. 2. Liquid chromatography-organic carbon detection (LC-ODR) spectra of different organic molecules from Acacia saligna biochar produced at $400^{\circ} \mathrm{C}$ and a mixture of this biochar with clay, chicken litter, and calcium carbonate baked at $220^{\circ} \mathrm{C}$ for $6 \mathrm{~h}$. (Source: biochar from Anthroterra Pty; LC-ODR Dr R Henderson UNSW.) Definitions: biopolymers, proteins and polysaccharides; humics, similar in structure and molecular weight to humic and fulvic acids standard; building blocks, oxidation products of humics; LMW acids and humics, low molecular weight humics and small acids, e.g. carboxylic; LMW neutrals, uncharged small organics; OND, organic nitrogen detection; UVD, ultraviolet detection. 
during a fire event in a mixed-hardwood forest. This contrasts with the findings of Kuzyakov et al. (2009), who did not detect presence of any dissolved organic $\mathrm{C}$ derived from ${ }^{14} \mathrm{C}$-labelled, black $\mathrm{C}$ residues from a rye-grass biochar that had been mixed with soil.

The precipitation reactions of inorganic compounds may be important, especially in soils subjected to wetting and drying cycles with minimal leaching. As the soil dries out, the ionic activity in solution increases. Once the ionic activity product reaches the saturation point, new precipitates are formed. These processes are enhanced within small pores, such as those present in biochars (Downie et al. 2009), as they have slow water percolation. This concentrates reaction products in solution and thus promotes precipitation (Lasaga 1998). In acid soils, a layer of either iron (hydr)oxide or alumina may deposit/ precipitate on part of the biochar (see section below: Observed changes over multiple years). In calcareous soils very low accumulations of $\mathrm{Fe}$ and $\mathrm{Al}$ oxy-hydroxides have been observed on the surface and in the pores of the biochar (N. Foidl et al., unpubl. data), which were dominated by the presence of carbonates.

\section{Redox reactions}

Decomposing organic detritus can be regarded as an electronpump supplying electrons to more oxidised species present in the soil system (Chesworth 2004). Biomass that has been converted to biochar is still thermodynamically unstable under the oxidative conditions of most surface soils (Fig. 3; Macías 2004; Macías and Camps Arbestain 2010), although it is evident that it remains in the soil as a meta-stable material with a much longer residence time than the original biomass from which it was formed. The chemical stability of charcoal is mainly due to the condensed aromatic structure, which is what distinguishes it from other more readily degradable aromatic substances such as lignin. Low-temperature biochars have, however, a considerable fraction of non-aromatic $\mathrm{C}$ (e.g. aliphatic C) (McBeath and Smernik 2009), which may make these biochars more susceptible to microbial attack, and thus to oxidation, than high-temperature biochars (Singh and Cowie 2008; Nguyen et al. 2010).

In spite of the high stability of aromatic $\mathrm{C}$, it has redox activity and mainly functions as a reducing agent, $\mathrm{O}_{2}$ being the most common electron-acceptor species. The oxidation of biochar is largely initiated through abiotic reactions boosted by the electron-donating properties of areas with a high density of $\pi$-electrons (Contescu et al. 1998), and followed by the subsequent formation of O-containing functional groups at the surface of the biochar, some of them acidic in nature (see next section). The presence of free radicals in biocharsthe amount being dependent on pyrolysis process conditions (Feng et al. 2004) - increases the reactivity towards oxidation, often to the point of being pyrophoric (Amonette and Joseph 2009). With increasing aromaticity, however, the stability of free radicals increases. In the absence of $\mathrm{O}_{2}$, alternative electron acceptors (e.g. $\mathrm{MnOOH}, \mathrm{MnO}_{2}$ in Fig. 3) may be able to oxidise aromatic C, as suggested by Nguyen and Lehmann (2009). Microorganisms can use aromatic compounds as the sole source of C (Hofrichter et al. 1999; Boonchan et al. 2000) or

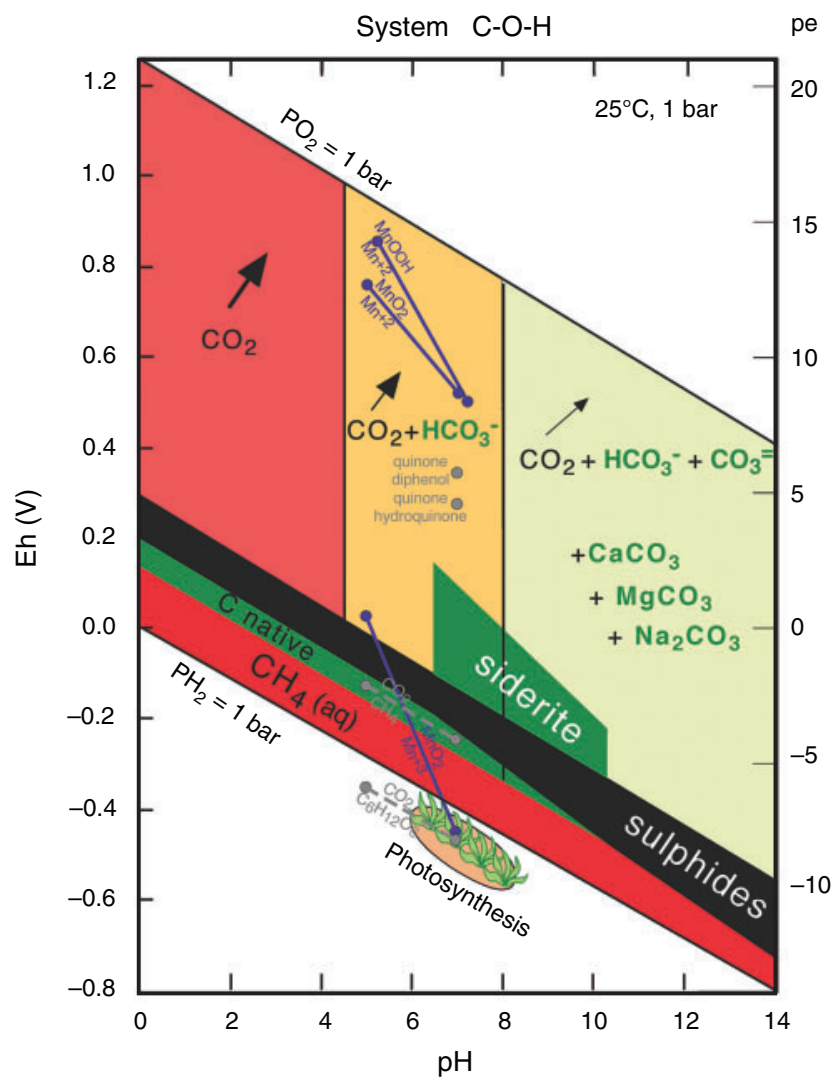

Fig. 3. Eh-pH diagram illustrating the predominance fields of stable $\mathrm{C}$ species $\left(\mathrm{CH}_{4}\right.$ and native $\mathrm{C}$ fields, Brookins 1988; siderite field, Chesworth 2004; quinone/diphenol and quinone/hydroquinone; Bartlett 1999). Extreme redox reactions of $\mathrm{Mn}$ are also included (Bartlett 1999) (modified from Macías and Camps Arbestain 2010 by Felipe Macías). Predominance fields are labelled in terms of the compounds that would be expected to form under the Eh and $\mathrm{pH}$ conditions of that specific field for specific set of conditions $\left(\mathrm{P}_{\mathrm{CO}_{2}} 10^{-3.5}\right.$ atm; $\mathrm{Fe}$ activity $10^{-6} ; \mathrm{S}$ activity $10^{-3}$; total pressure $1 \mathrm{~atm}$; standard temperature $25^{\circ} \mathrm{C}$ ). The predominance field of sulfides and the geochemical fences of some Mn species are also included.

degrade them through co-metabolic decomposition (Kuzyakov et al. 2009).

Aromatic compounds are not only potential $\pi$-electron donors, but also $\pi$-electron acceptors. They become stronger $\pi$-donors as the number of aromatic rings increases, whereas the presence of $\mathrm{N}$ substituents in the rings can create either electronrich systems (e.g. indoles) or electron-depleted ones (e.g. 2,4,6trinitrotoluene) (Keiluweit and Kleber 2009). The role of $\mathrm{N}$ substituents present in the different types of biochars in $\pi-\pi$ electron donor-acceptor-type interactions (referred to as EDA) deserves further investigation. When $\pi$ orbitals overlap with $\mathrm{d}$ orbitals from many transition-series metals, stable complexes are formed, and these are important for catalysis.

Overall, from a thermodynamic standpoint (Kennedy 2001), the entropy (the degree of order) and the enthalpy (heat of formation) change continuously and these systems go from one steady-state to another. The free energy of the biochar surfaces may thus change as microbial and root activity, oxygen and water content, and soil temperature change. The free energy of the internal structure may also continually change as dissolved 
organic and inorganic compounds move into, and out of, the macropores.

\section{Acidic and basic surface charge of biochars}

Biochar surfaces can initially have acidic as well as basic properties (Cheng et al. 2008; Amonette and Joseph 2009), which have an important influence on both the wettability of biochar particles and the surface retention of ions through electrostatic interactions (Boehm 2001). Although acidic and basic sites usually coexist, the concentration of basic sites decreases through oxidative processes as the biochar particle weathers (Cheng et al. 2008; Cheng and Lehmann 2009). The functional groups likely to be formed with this process are carboxylic, lactonic, phenolic, carbonyl, o-quinone-like structures, and ether-type oxygen (Boehm 2001). The first 3 groups have Brønsted acidic properties and provide a $\mathrm{pH}-$ dependent cation exchange capacity to biochar particles.

Recent studies using X-ray photoelectron spectroscopy (XPS) of the structural changes occurring in biochar particles 1 year after their application to soils showed a predominant increase of carbonyl and, to a lesser extent, of carboxylic functional groups with prolonged weathering (see section below: Observed changes over multiple years). The same trend was observed by Cheng et al. (2008), investigating the changes in the molecular form and surface charge of aged charcoal particles sampled from historical charcoal blast furnace sites. The smaller increase observed in carboxylic groups - although still substantial and having a key role in nutrient retention-compared with carbonyl groups (Cheng et al. 2008; see Observed changes over multiple years) could be due to the lower stability of the former. Once in solution, these groups can become partly decarboxylated through hydrolysis reactions (Yan et al. 1996).

While the nature of the acidic surface sites is well understood, the nature of basic sites on $\mathrm{C}$ surfaces is a controversial issue (Leon y Leon et al. 1992; Contescu et al. 1998; Montes-Morán et al. 2004). Traditionally, oxygen-containing groups (e.g. pyrone type, chromene, diketone, or quinone groups) and delocalised $\pi$-electrons of the basal planes are assumed to have a basic nature (Contescu et al. 1998; Montes-Morán et al. 2004). While pyrone undergoes Brønsted acid-base reactions, proton transfer processes to and from the other surface groups occur simultaneously with redox reactions (Contescu et al. 1998). Stabilised free radicals present in the basal planes may also contribute to basicity (MontesMorán et al. 2004).

\section{Sorption of organic compounds on biochar surfaces}

Once biochar is added to the soil, it can adsorb organic molecules (Pignatello et al. 2006), including residual herbicides and pesticides (Smernik 2009; Spokas and Reicosky 2009). Numerous mechanisms can be involved in the interactions of biochars with organic compounds, including H-bonding, cation-bridging, covalent bonding, and hydrophobic types of interactions. In addition, there is increasing evidence of the important role of mechanisms involving non-covalent EDA interaction between $\pi$-systems of organic compounds and sorption sites at soil mineral surfaces, natural organic matter, and biochar (Keiluweit and Kleber 2009).

Reaction rates for the adsorption processes of organic molecules onto biochar particles depend on the characteristics of the adsorbate as well as on the surface properties of the adsorbent. Polar compounds are more likely to be adsorbed on surfaces with high oxygen functionality, although Zhu et al. (2005) found that these functionalities were not the principal driving force for sorption of polar compounds. The adsorptive properties of biochar particles may become attenuated with time as the external space available for adsorption reactions diminishes with the increasing presence of organic compounds at the surface (Pignatello et al. 2006). As organic and mineral matter builds up on the surface of the biochar, the type of compounds involved in surface reactions and the adsorption rates will change (Kwon and Pignatello 2005; Keiluweit and Kleber 2009). In some instances, adsorption processes might be difficult to distinguish from surface oxidation reactions (Lehmann et al. 2005; Dias et al. 2010).

\section{Biochar-soil mineral-soil organic-matter interactions}

Interactions between organic matter and clay mineral surfaces in soil are complex and depend on the type of clay $(2: 1,1: 1)$, the distribution of different functional groups on the clay (siloxane, $\mathrm{OH})$ and the organic matter $(\mathrm{COOH}, \mathrm{C}=\mathrm{O}, \mathrm{C}-\mathrm{O}, \mathrm{CN})$, the polarity of these compounds, and the composition and concentration of cations and anions in solution (Kleber et al. 2007). Similar complex reactions are likely to take place on biochar surfaces, especially for those biochars that have high mineral content. Based on the literature related to organic matter and mineral interactions, and on the mechanisms described in previous sections, several mechanisms for interactions between biochar and organic matter and/or minerals in soil can be hypothesised as follows:

(i) Surface hydrophobic and hydrophilic interactions of biochar, organic compounds, and clay minerals, following the conceptual model of organo-mineral interactions proposed by Kleber et al. (2007). This occurs through direct electrostatic interactions, $\mathrm{H}$ bonding, cation bridging, and ligand exchange reactions in the hydrophilic zone (Yariv and Cross 2002), whereas the bi-layer formed in the hydrophobic zone is entropically driven (Kleber et al. 2007);

(ii) EDA interactions can occur between aromatic compounds (including biochar) and mineral surfaces, as well as between 2 aromatic compounds, as described in detail by Keiluweit and Kleber (2009);

(iii) Soluble organic compounds released from the biochar particles and/or from other organic matter in soil can become intercalated within $2: 1$ and $1: 1$ clay minerals. Replacement of interlayer water in smectites by neutral organic molecules and binding of organic compounds in tubular kaolinites through strong hydrogen bonds and/or strong dipole interaction to silicate layers have been reported (Lagaly 1984; Matusik et al. 2009);

(iv) Deprotonated multidentate organic acids are known to form complexes with transition metals (Violante and Gianfreda 2000) and also silicic acid (Marley et al. 1989). 
Macropore filling and interactions with microorganisms, dissolved organic matter and minerals

Most biochars have a high concentration of macropores with a diameter $>1 \mu \mathrm{m}$ that extend from the surface of the particle into its interior (Downie et al. 2009). After continuous irrigation or heavy rain events, a high water-potential gradient can be generated between the inner and outer part of the pore channels (Hillel 2004). Capillary forces draw soil solution into the microvoids, if biochar is not too hydrophobic, and small mineral and organic particles carried in suspension accumulate in the pore channels (Fig. 4). This process is favoured if the electrolyte concentration of soil water is low, as this enhances clay dispersion (Buurman et al. 1998), and if coarser material does not clog the pore system. The depth to which these particles penetrate the biochar depends on the diameter, tortuosity, connectivity, and length of the macropores, and also on the size of the particles. Reactions in pores can be very complicated given the heterogeneous nature of the surfaces of the solid biochar, mineral and organic phases/ compounds, and the complexity of the dissolved organic and inorganic matter in the liquid phase that surround the solids (Hammes and Schmidt 2009). These include dissolution and precipitation reactions (see Overview) and sorption reactions described in previous sections.

The porous structure of biochar is likely to provide microorganisms with a highly suitable habitat to colonise. Ogawa (1994) has noted that fungi grow from within the pores out into the soil. Thies and Rilling (2009) reported the existence of a range of microbial communities within pores. These microbes might decompose organic matter adsorbed on the biochar surface and within pores (Zackrisson et al. 1996); however, the extent of this decomposition will be mainly related to accessibility and the amount of chemical energy required for the enzymatic cleavage of chemical bonds (Kögel-Knabner et al. 2008).

Liang et al. (2010) observed that, in spite of the greater microbial biomass detected in charcoal-rich soils, these have a lower microbial metabolic quotient, and suggested the presence of a less-active fraction of microorganisms in the charcoal- amended soil than in soils without charcoal. The composition of these communities will also depend on the $\mathrm{pH}$ and $\mathrm{Eh}$ at the micro-site. As oxygen is depleted within the inner pores, facultative aerobes may begin to use anaerobic respiratory pathways, and the redox potential will decrease as the concentration of the most favourable electron acceptors is depleted. However, biochar addition to soil may increase soil aeration because of its highly porous nature, and hence decrease the total amount of anaerobic microsites per unit volume of soil.

\section{Interactions with plant roots and microorganisms in the rhizosphere}

A complex set of reactions may occur between plant roots, microorganisms, and biochars. In most agricultural applications, biochars will have interacted with soils, following the reactions described in the previous section, before the root hairs come into contact, increasing the complexity of these interactions. Microscopic, chromatographic, and spectroscopic studies of biochar and root growth in biochar-amended systems suggest the following interactions may occur.

Once the root system encounters a biochar particle, root hairs can enter the water-filled macropores or bond onto the biochar surface (Fig. 5a, b). Biochars and minerals associated with biochar particles can adsorb organic compounds released from the growing roots, following the mechanisms described above (in Sorption of organic compounds on biochar surfaces). These include low-molecular weight organic compounds (free exudates), high-molecular-weight gelatinous material (mucilage), and sloughed-off cells and tissues and their lysates (Violante and Gianfreda 2000). These compounds can bind either to the mineral layers on the biochar or directly to the biochar surfaces. The rhizosphere constitutes an important redox interface, as the reducing and oxidising environments are intimately associated with one another (Bartlett 1999). Biochar might change the complex redox potential existing in this zone, altering reactions involving free radicals. These redox reactions include transformations of $\mathrm{C}, \mathrm{N}$, and $\mathrm{S}$, which can involve reactions with $\mathrm{Fe}$ and $\mathrm{Mn}$ species.
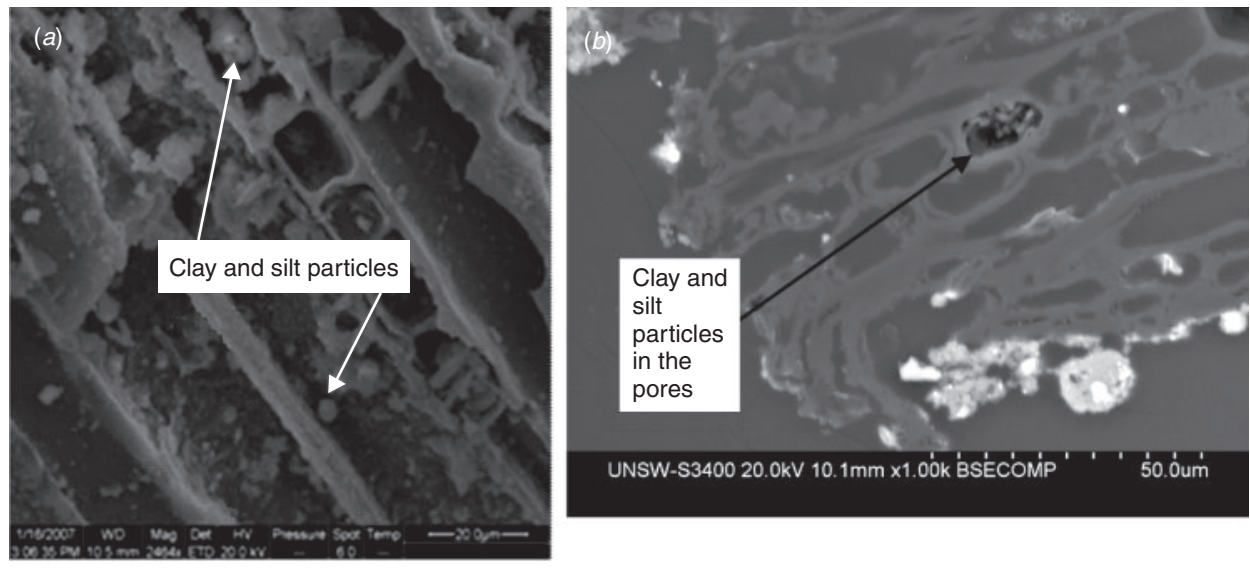

Fig. 4. (a) SEM image showing clay and silt particles entering the macropores of the greenwaste biochar. (b) Inside a sectioned particle (around the middle) of greenwaste biochar. The lighter areas around the biochar are mineral matter with variable composition. (Source: EMU UNSW.) 

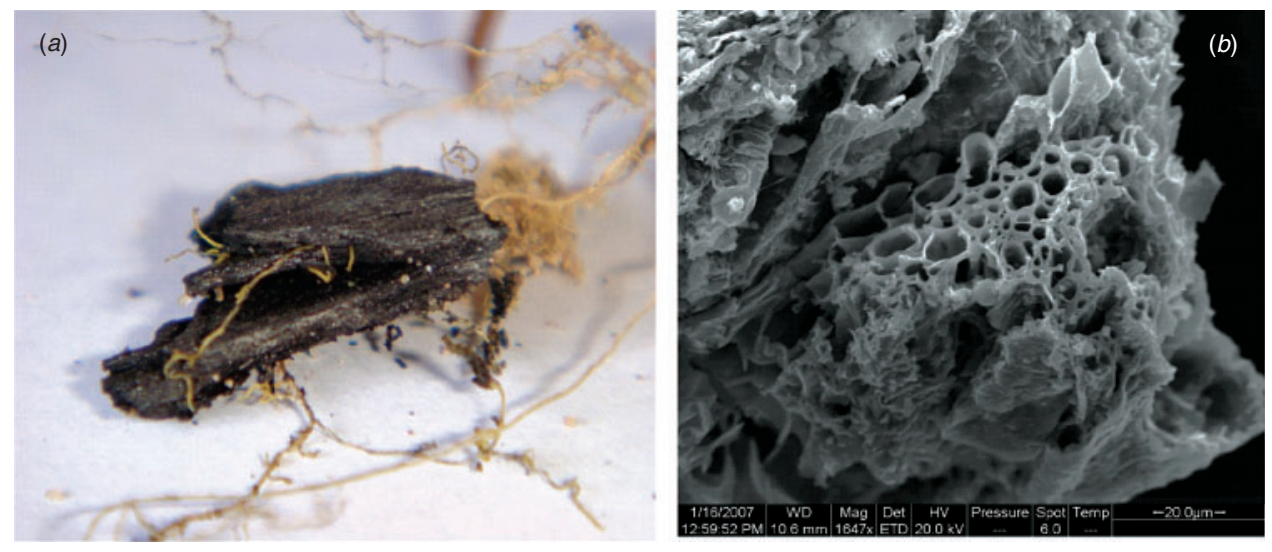

Fig. 5. (a) Optical image showing root hairs penetrating a biochar particle that has been in soil for 20 years (source N. Foidl from Bolivian soil). (b) SEM image showing a root hair within a chicken manure biochar after 1 year in soil. (Source: EMU UNSW.)

Biochar has also been shown to adsorb toxic compounds of natural (MacKenzie and DeLuca 2006; Pignatello et al. 2006; Cheng and Lehmann 2009) and anthropogenic (Smernik 2009; Spokas and Reicosky 2009) origin (see Sorption of organic compounds on biochar surfaces) and decrease their activity. This is the case for phenolics produced during decomposition of ericaceous vegetation, the net result of which is an increase in nutrient availability through enhanced nitrification (Wardle et al. 1998; Berglund et al. 2004; MacKenzie and DeLuca 2006). High concentrations of phenolic acids, such as $p$-coumaric and $p$-hydroxybenzoic, have also been reported to impair root elongation and affect the metabolism of IAA, a major auxin (Marschner 1999). The activity of other organic compounds, such as tyrosinase, a phenol oxidase enzyme that assists in the breakdown of organic matter, has been suggested to be promoted in the presence of highly microporous charcoal and $\mathrm{Fe}$ and Mn oxides (Amonette et al. 2006). Biochar may have a more fundamental effect on plant root and soil microbe growth, through a range of organic molecules that could be present in the volatile fraction of biochars. Some of these compounds (e.g. butenolide) can trigger germination (Dixon 1998), while others (e.g. sesquiterpenes; Bridgwater and Boocock 2006) can promote the growth of mycorrhizal fungi (Amonette and Joseph 2009). Auxofuran could play a major role in assisting plant uptake of nutrients (Riedlinger et al. 2006).

Root redox potential and membrane-associated redox activities influence a wide range of other cell functions, including the activity of many enzymes, the expression of many genes (Quaggiotti et al. 2004), and the activity of cytosolic redox buffers and several plasma membrane oxidoreductases (Arvieu et al. 2003). Changes in redox potential may also influence the plant growth regulator, IAA, in the region of the embryo that will become the root (Tarkka et al. 2008). Biochar is likely to adsorb the ethylene produced by the plants, as has been suggested in sand cultures using activated charcoal (Michael 2001). Conversely, some evidence for the emission of ethylene by biochars suggests a more active role of biochar in inhibiting the nitrification process in soils that leads to nitrous oxide emissions (Spokas and Reicosky 2009). More information is needed from biochar-amended soil studies.

\section{Possible negative effects of biochar addition}

Little is known about the potential toxic effects of biochar in soil, and specifically of those related to the presence of heavy metals and plant-available organic compounds that have condensed on the surfaces of biochar during their manufacture. A discussion of possible effects is given in Lehmann and Joseph (2009). The following is a brief summary.

Condensates on the surface of biochars may contain compounds such as polycyclic aromatic hydrocarbons, cresols, xylenols, formaldehyde, acrolein, and other toxic carbonyl compounds that can have bactericidal or fungicidal activity (Painter 2001). However, Ogawa (1994) has shown that these substances can, and do, serve as $\mathrm{C}$ and energy sources for selected microbes. McClellan et al. (2007) found that residual volatiles on biochar made using a flash carboniser proved toxic to plants. When the biochar soaking time was increased these toxic effects were removed.

\section{Observed changes over multiple years}

Biochars produced at $450^{\circ} \mathrm{C}$ (chicken litter) and $550^{\circ} \mathrm{C}$ (papermill waste and greenwaste) were characterised before application and at 1 and 2 years after application to a Ferrosol (Australian Soil Classification System) in a subtropical environment at Wollongbar (NSW, Australia, $28^{\circ} 50^{\prime} \mathrm{S}, 153^{\circ} 25^{\prime} \mathrm{E}$ ). A summer sweet corn-winter pulse rotation was established at the site. The feedstocks, pyrolysis conditions, sampling procedures, and analytical techniques are described in the Accessory publication (available on journal website) and are also reported in Chan et al. (2008) and Van Zwieten et al. (2010).

The surfaces of the weathered biochar particles were found to be heterogeneous, covered with a wide variety of mineral and organic matter, and very different from the surfaces of the fresh biochars, as shown in the SEM images in Fig. 6. At these surfaces, high concentrations of clay minerals consisting of various combinations of $\mathrm{Al}, \mathrm{Si}, \mathrm{C}, \mathrm{Fe}$, and $\mathrm{Ti}$, and trace amounts of $\mathrm{Ca}, \mathrm{Mg}, \mathrm{Mn}, \mathrm{K}, \mathrm{Na}, \mathrm{P}$, and $\mathrm{S}$, were found using detailed electron microprobe analysis of cross-sectioned samples of a greenwaste biochar (Fig. 7). This figure demonstrates that 

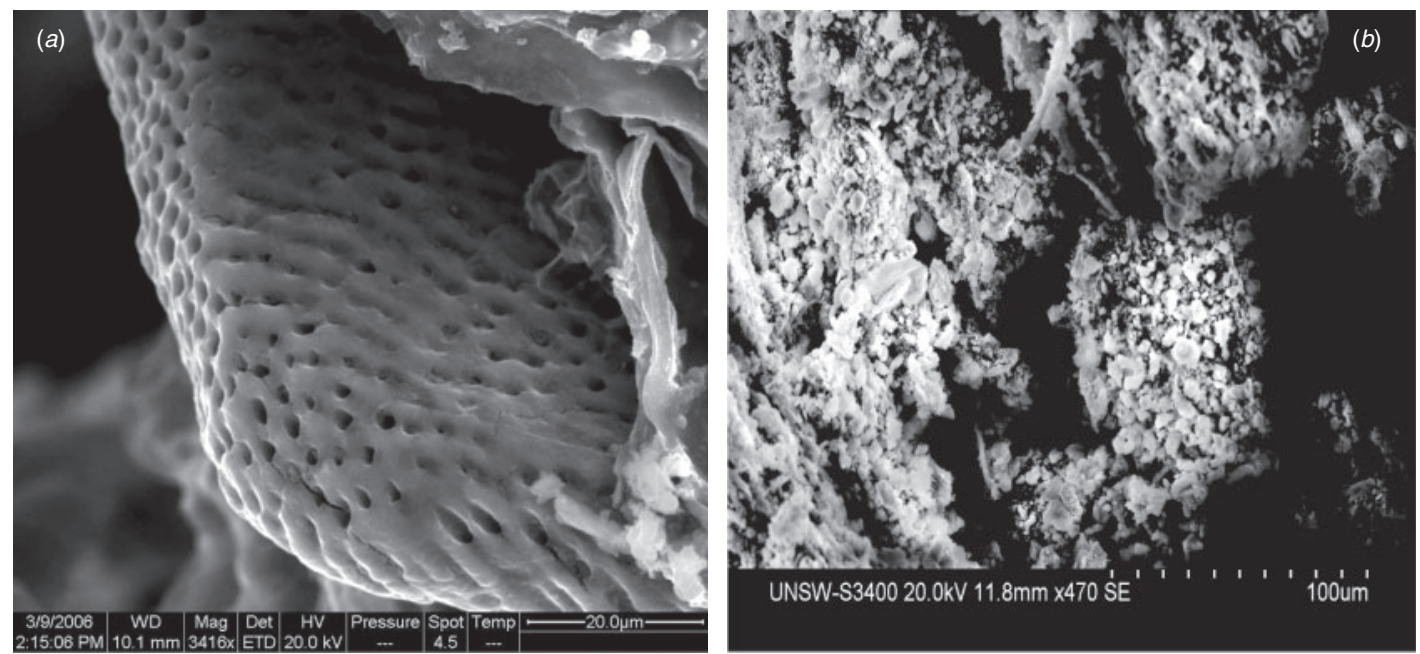

Fig. 6. SEM images showing $(a)$ the external surface of a fresh chicken manure biochar (note the structure is a function of the feed material); (b) the surface of the same biochar after 1 year in soil. (Source: Biochar BESTEnergies; image EMU UNSW.)
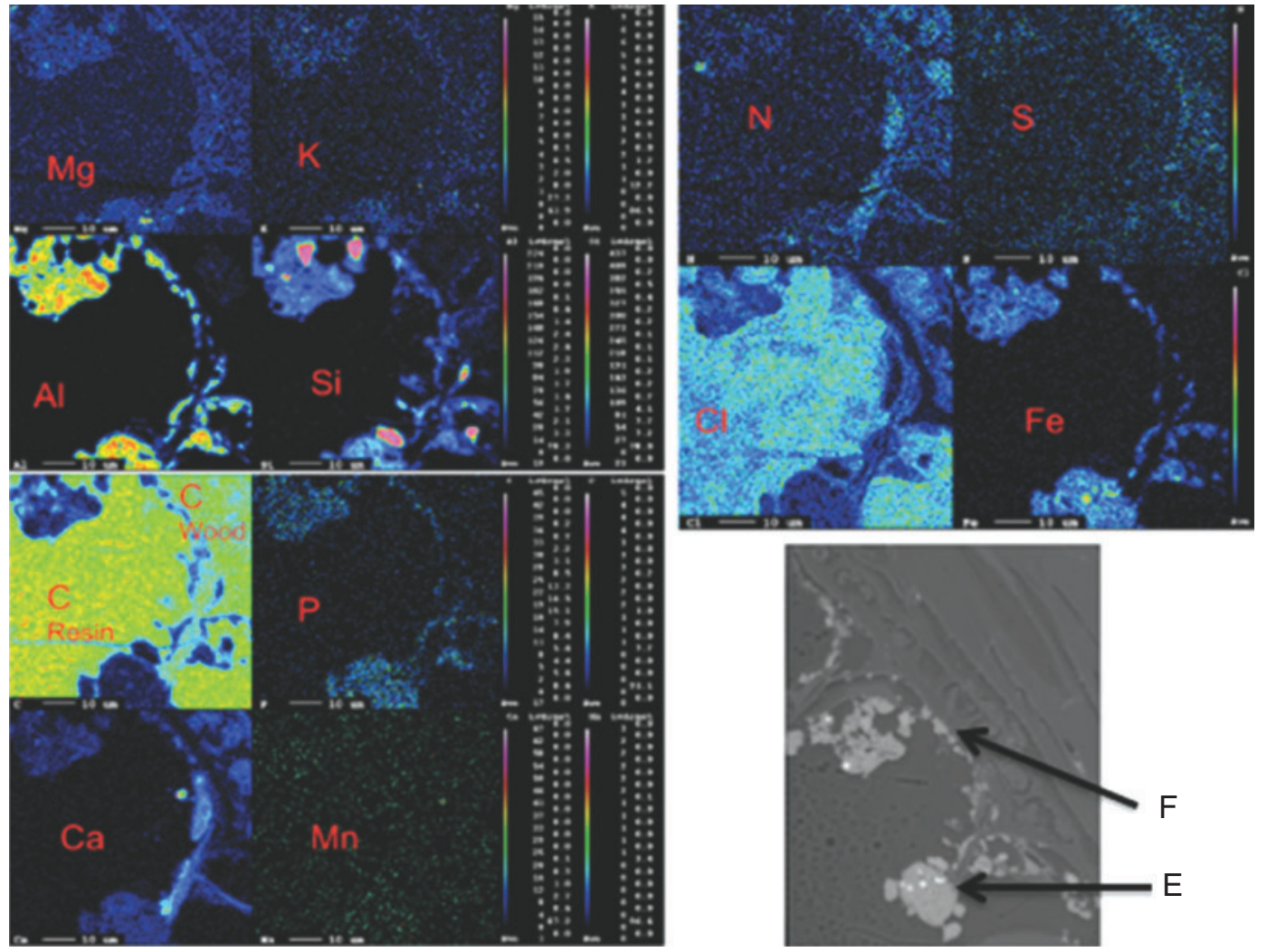

Fig. 7. Electron microprobe elemental maps of elements on a section of a GW biochar particle after 1 year in soil. Note the high concentration of minerals around the extremity of the biochar (E) and on the flat surface (F). The SEM image of the analysed area is also shown. (Source: The brighter the area the higher the concentration; EMU UNSW.)

most of the inorganic phases are located at the external surfaces of a greenwaste biochar particle. The P-rich components are mostly associated with high $\mathrm{Fe}$ concentrations, but also with high $\mathrm{Al}$ and $\mathrm{Si}$, suggesting either precipitation (e.g. Fe, Alphosphates) and/or sorption interactions on $\mathrm{Al}$ and $\mathrm{Fe}$ oxy- hydroxides and aluminosilicate minerals. Nitrogen, $\mathrm{S}$, and $\mathrm{Ca}$ compounds were identified on the inner flat surface of the weathered greenwaste biochar. This could indicate that a range of calcium polysaccharides, proteins, and amino acids have complexed on the surface. Overall, examination of 
sectioned samples of the different biochars using SEM and transmission electron microscopy (TEM) (data not shown) indicated that only some of the pores had a range of organic and mineral matter after the first year, whereas most of the pores were filled after a second year in the soil.

Energy dispersive X-ray spectrometry (EDS) analysis, in conjunction with scanning TEM was performed across the organomineral/biochar interfaces to examine both the pores and the surfaces of the 3 biochars aged for 1 year in soil. Figure 8 shows a cross-section of an organo-mineral particle complexed onto the surface of a chicken litter biochar particle (aged 1 year). EDS measurements showed a phase rich in $\mathrm{Al}$ and $\mathrm{O}$ within a pore of the $\mathrm{C}$ matrix adjacent to the interface. In this region, the phase was also rich in $\mathrm{C}$ and had small amounts of $\mathrm{Ca}$ and Si. Adjacent to this phase, there was a phase containing a mixture of $\mathrm{Al}$ and $\mathrm{Fe}$ oxy-hydroxides and aluminosilicate particles. These inorganic particles appeared to be associated with $\mathrm{C}$ compounds and had a significant $\mathrm{Ca}$ content. The region was also enriched in $\mathrm{P}$, similar to results obtained with greenwaste biochar using the electron microprobe (Fig. 7). The EDS maps and line scans obtained for the aged papermill waste biochar (data not shown) also revealed a range of $\mathrm{Al} / \mathrm{Si} / \mathrm{O}$ and $\mathrm{Fe}$ phases bonded to the amorphous $\mathrm{C}$ phase, which were not seen in the fresh papermill waste biochar. The Fe concentration in the papermill waste was also lower than that observed in the other biochars.

Results of XPS analysis of the surfaces (Table 1) indicate that the fresh greenwaste biochar and poultry manure biochar consisted only of $\mathrm{C}$ and $\mathrm{O}$, with $\mathrm{O} / \mathrm{C}$ ratio $<0.2$. After 1 and 2 years in the soil, the $\mathrm{C}$ content of this biochar decreased. The total surface $\mathrm{O}$ and $\mathrm{O}$ bound to $\mathrm{C}$ increased, leading to $\mathrm{O} / \mathrm{C}$ ratios of $\sim 0.75$. The aged greenwaste biochar showed the largest decrease in surface $\mathrm{C}$, whereas the aged papermill waste had the highest $\mathrm{C}$ content among the 3 aged biochars. With respect to $\mathrm{C}$ bonding states (Table 1), $\mathrm{C}-\mathrm{C} / \mathrm{C}-\mathrm{H} / \mathrm{C}=\mathrm{C}(\sim 284.9 \mathrm{eV})$ was the major component in all fresh and aged biochars, but the relative content of these bond types sharply decreased after
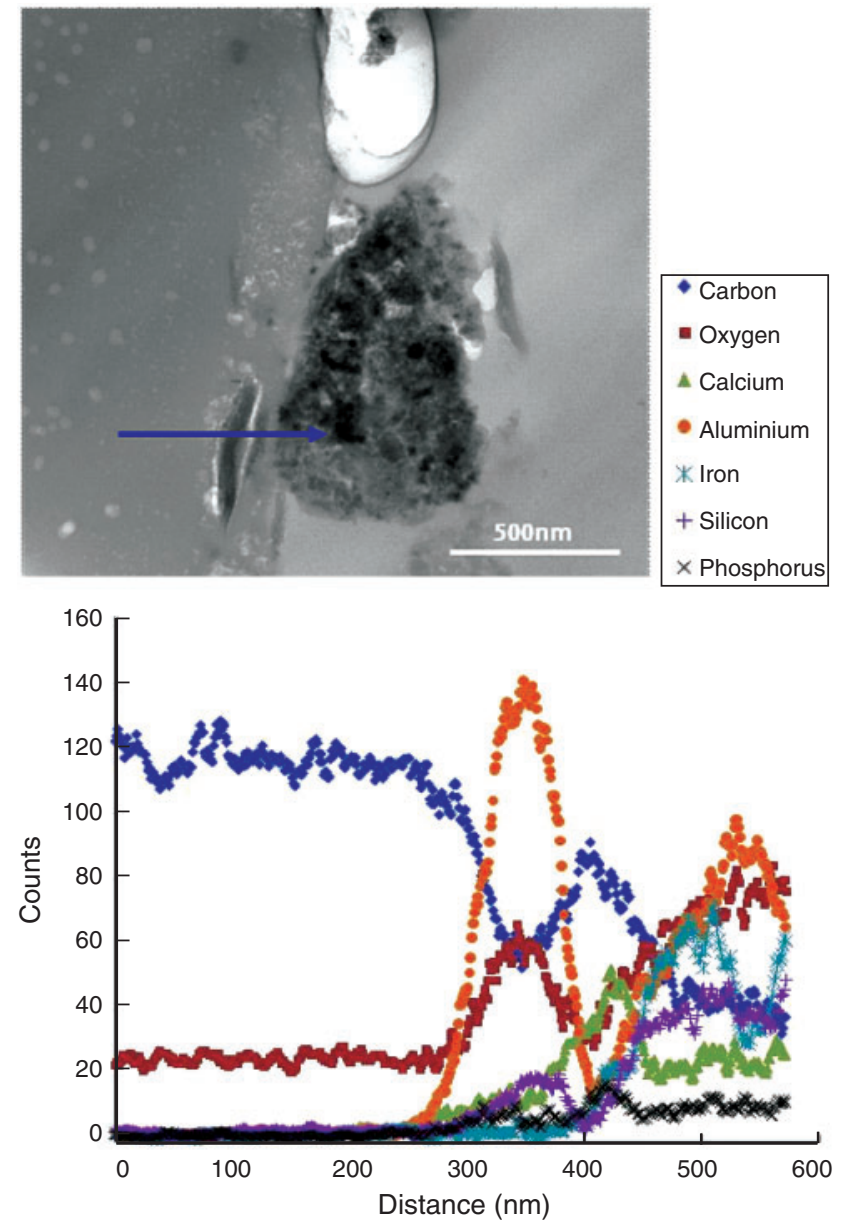

Fig. 8. TEM bright field image and EDS elemental line scan across an interface between the surface of a CL biochar piece (left) and an organomineral phase that has reacted with the surface of a 1-year old biochar. The line on the TEM image denotes the location of the line scan. The area on the right is resin used to hold the sample.

Table 1. XPS results of fresh and aged greenwaste biochar after 1 and 2 years of weathering in an Australian Ferrosol n.d., Not detected

\begin{tabular}{|c|c|c|c|c|c|c|c|c|c|c|c|c|c|}
\hline \multirow[t]{2}{*}{ Transition } & \multirow{2}{*}{$\begin{array}{l}\text { Assigned } \\
\text { structure }\end{array}$} & \multicolumn{3}{|c|}{ Peak energy $(\mathrm{eV})$} & \multicolumn{3}{|c|}{ Abundance (atom \%) } & \multicolumn{3}{|c|}{ Organics only } & \multicolumn{3}{|c|}{ C1s only } \\
\hline & & Fresh & 1 year & 2 year & Fresh & 1 year & 2 year & Fresh & 1 year & 2 year & Fresh & 1 year & 2 year \\
\hline \multirow[t]{4}{*}{ O1s } & $\mathrm{O}-\mathrm{C}$ & 533.42 & n.d. & n.d. & 10 & 0 & 0 & 10 & 0 & 0 & & & \\
\hline & Chemisorbed oxygen? & 531.46 & n.d. & n.d. & 6 & 0 & 0 & 6 & 0 & 0 & & & \\
\hline & Silicates & n.d. & 532.84 & n.d. & 0 & 47 & 0 & 0 & 56 & 0 & & & \\
\hline & Subtotal O1s & & & & 15 & 47 & 19 & 15 & 56 & 21 & & & \\
\hline \multirow[t]{5}{*}{$\mathrm{C} 1 \mathrm{~s}$} & $\mathrm{C}=\mathrm{O}$ & 288.30 & 288.08 & 287.77 & 2 & 6 & 12 & 2 & 7 & 13 & 2 & 16 & 17 \\
\hline & $\mathrm{C}-\mathrm{O}$ & 286.50 & 286.58 & 286.24 & 14 & 12 & 20 & 14 & 14 & 22 & 17 & 34 & 28 \\
\hline & $\mathrm{C}-\mathrm{C} / \mathrm{C}-\mathrm{H}$ & 284.96 & 284.89 & 284.87 & 69 & 14 & 36 & 69 & 16 & 38 & 81 & 41 & 48 \\
\hline & $\mathrm{COOH}$ & n.d. & 289.17 & 289.71 & 0 & 3 & 6 & 0 & 4 & 6 & 0 & 9 & 8 \\
\hline & Subtotal C1s & & & & 85 & 34 & 74 & 85 & 40 & 78 & 100 & 100 & 100 \\
\hline \multirow[t]{3}{*}{ N1s } & $\mathrm{N}-\mathrm{C}-\mathrm{COOH}$ & n.d. & 400.51 & 400.25 & 0 & 3 & 1 & 0 & 3 & 1 & & & \\
\hline & $\mathrm{NH}_{4}^{+}$ & n.d. & n.d. & 401.49 & 0 & 0 & 0 & 0 & 0 & 0 & & & \\
\hline & Subtotal N1s & & & & 0 & 3 & 1 & 0 & 3 & 1 & & & \\
\hline Organics only & Subtotal organics & & & & 100 & 84 & 94 & 100 & 100 & 100 & & & \\
\hline $\mathrm{Si} 2 \mathrm{p}$ & Silicates & n.d. & 103.02 & 103.05 & 0 & 7 & 2 & & & & & & \\
\hline $\mathrm{A} 12 \mathrm{p}$ & Silicates & n.d. & 74.61 & 74.90 & 0 & 8 & 3 & & & & & & \\
\hline \multirow[t]{2}{*}{$\mathrm{Fe} 2 \mathrm{p} 3 / 2$} & $\mathrm{FeS} ?$ & n.d. & 712.84 & 713.05 & 0 & 1 & 0 & & & & & & \\
\hline & Total & & & & 100 & 100 & 100 & & & & & & \\
\hline
\end{tabular}


Table 2. XPS results for the $\mathrm{O} 1 \mathrm{~s}, \mathrm{C} 1 \mathrm{~s}$, and N1s core level of fresh and aged chicken litter biochars after 1 and 2 years of weathering in an Australian Ferrosol

n.d., Not detected

\begin{tabular}{|c|c|c|c|c|c|c|c|}
\hline \multirow[t]{2}{*}{ Transition } & \multirow{2}{*}{$\begin{array}{l}\text { Assigned } \\
\text { structure }\end{array}$} & \multicolumn{3}{|c|}{ Peak energy (eV) } & \multicolumn{3}{|c|}{ Abundance (atom \%) } \\
\hline & & Fresh & 1 year & 2 year & Fresh & 1 year & 2 year \\
\hline \multirow[t]{3}{*}{$\overline{\mathrm{O} 1 \mathrm{~s}}$} & $\mathrm{O}-\mathrm{C}$ & 533.71 & n.d. & 533.01 & 9 & 0 & 32 \\
\hline & Silicates? & 532.33 & 532.30 & n.d. & 19 & 42 & 0 \\
\hline & Subtotal O1s & & & & 25 & 42 & 32 \\
\hline \multirow[t]{7}{*}{$\mathrm{C} 1 \mathrm{~s}$} & $\mathrm{C}=\mathrm{O}$ & 288.01 & 288.01 & 288.32 & 4 & 6 & 9 \\
\hline & $\mathrm{C}-\mathrm{O}$ & 286.61 & 286.50 & 286.72 & 10 & 15 & 18 \\
\hline & $\mathrm{C}-\mathrm{C} / \mathrm{C}-\mathrm{H}$ & 285.01 & 284.94 & 285.05 & 36 & 17 & 22 \\
\hline & $\mathrm{COOH}$ & n.d. & 289.24 & 289.60 & 2 & 2 & 6 \\
\hline & Carbonate & 290.58 & n.d. & n.d. & 3 & 0 & 0 \\
\hline & Subtotal C1s & & & & 55 & 40 & 55 \\
\hline & $\mathrm{N}-\mathrm{C}$ & 399.10 & 398.86 & 399.49 & 1 & 1 & 1 \\
\hline \multirow[t]{3}{*}{ N1s } & $\mathrm{N}-\mathrm{C}-\mathrm{COOH}$ & n.d. & n.d. & 400.74 & 0 & 0 & 2 \\
\hline & $\mathrm{NH}_{4}^{+}$ & 402.12 & 400.20 & 402.10 & 0 & 3 & 1 \\
\hline & Subtotal N1s & & & & 1 & 4 & 4 \\
\hline Organics only & Subtotal organics & & & & 81 & 86 & 87 \\
\hline
\end{tabular}

application to soil. The amount of $\mathrm{C}$ in more oxidised states was increased, which indicated that the oxidation of the surface and/ or adsorption of soil organic matter had occurred. There was little difference between the first and second year for the relative oxidation status of the $\mathrm{C}$ species (Table 1). The surfaces of all of the aged biochars had increased $\mathrm{N}$ content mainly associated with proteins and amino acids $(\sim 400.2 \mathrm{eV})$ and $\mathrm{NH}_{4}{ }^{+}$ $(\sim 401.5 \mathrm{eV})$ and $\mathrm{N}-\mathrm{C}(\sim 399.5 \mathrm{eV})$ compounds (Table 2$)$. The greatest increase in surface $\mathrm{N}$ content was in the papermill waste biochar; the high content of $\mathrm{Ca}$ on the papermill waste surfaces may result in $\mathrm{Ca}$ bridging with the nitrogenous compounds in the soils.

The ${ }^{13} \mathrm{C}$ CP-NMR spectra of the fresh and 1-year weathered biochars (Fig. 9) shows that the weathered PM biochar contains 2 additional peaks in the O-alkyl area, compared with the fresh biochar, suggesting either incomplete separation of biochar from soil organic matter or the existence of organo-biochar interactions at the surface of the biochar particle. The weathered greenwaste biochar is very similar to the original biochar, except for a slightly less prominent O-aryl shoulder $(\sim 150 \mathrm{ppm})$ and slightly less alkyl C ( 30 ppm). This could be related to a faster decomposition of the non-aromatic $\mathrm{C}$ fraction. Differences in NMR spectra between the fresh and the weathered chicken litter biochar are most likely due to the presence of artefacts from soil particles in the latter. Finally, the degree of aromatic condensation of the fresh and aged biochars were determined using the method of McBeath and Smernik (2009), which is based of the effect of biochar ring currents on sorbed ${ }^{13} \mathrm{C}$-benzene. This indicated that the papermill waste and chicken litter biochars taken from the soil after 1 year had a lower degree of aromatic condensation than for the corresponding fresh papermill biochars, whereas the greenwaste biochar showed the opposite trend (Fig. 10). This suggests that ageing of papermill and chicken litter biochars results in biochar surfaces with a lower degree of aromatic condensation, through oxidation of the surface or precipitation or sorption of inorganic or organic materials on the surface.

\section{Biochar and soil fauna}

Some worms, termites, larvae, and other insects appear to ingest or live inside biochar (Fig. 11) breaking it up and/or coating it with organic compounds. Breaking up the biochar can result in exposed surfaces being oxidised and then reacting with mineral or organic matter as discussed in Initial reactions of biochar when placed in the soil. Eckmeier et al. (2007) noted that earthworms ingest particles $<2 \mathrm{~mm}$ (but do not digest them) and redistribute them elsewhere in the profile (concentrated at $\sim 0.8 \mathrm{~m}$ depth) by excretion, as shown by thin sections of soil with small biochar particles present in earthworm casts. Bioturbation can thus have an important role in the physical mixing of biochar particles and its re-distribution within the soil profile. Over time, biochar will tend to move down through the soil profile (Major et al. 2009a) to areas where microbial activity is lower.

\section{Conclusions: towards an understanding of the dynamics of biochar reactions}

The limited data available indicate different biochars undergo a range of complex reactions in soil that vary depending on the particular properties of the biochars and soils involved. Factors such as nutrient composition and availability, organic matter content, soil mineralogy and texture, $\mathrm{pH} /$ Eh conditions, presence of toxins, soil biota, the type of plants grown, the proximity of the biochars to the rhizosphere, and the temporal variation in soil moisture can all impact the nature of biochar reaction.

Although not conclusive, data from both pot and field trials suggest the following series of time-sequenced reactions takes place:

1. When high mineral ash biochars are added to moist soil (or are followed by a rain event) there is a change in the $\mathrm{pH}, \mathrm{EC}$, and Eh around the particle, probably within the first week, as the minerals dissolve and/or ions are exchanged on the surfaces of the surrounding clay particles.

2. For high-porosity biochars, a rain event can also result in the inclusion and enhanced surface interaction of a range of soil 
mineral and organic compounds with the biochar particles (Fig. 4). The limited data available indicate that the type of reactions that take place and the stability of the compounds retained on the surface depend on the type of biochar and the conditions under which it was produced (Spokas and Reicosky 2009; Nguyen et al. 2010). Any significant reaction involving the biochar, the soil mineral, and dissolved organic matter could lead to a substantial change in the properties of the biochar (e.g. pH and EC).

3. When biochars produced at low temperatures are added to moist soils, a considerable quantity of soluble organics can be released to the soil solution (Fig. 1). As noted by Dixon (1998) and Light et al. (2009), some of the labile organic compounds on the surfaces of biochar can stimulate both seed germination and growth of fungi. Little is known, however, about the toxicity of these compounds.

4. The enhanced $\mathrm{CO}_{2}$ emissions observed during the first months after biochar addition to soil are partly attributed to biochar surface oxidation. There are several different biotic and abiotic reaction mechanisms involved.
High mineral ash biochars have been shown to oxidise faster than low mineral ash biochars. It is possible that the mineral matter in the biochar provides nutrients for microorganisms to grow faster as well as catalysing the breakdown of organic matter (Amonette et al. 2006). The higher the temperature of pyrolysis, the higher the resistance of the $\mathrm{C}$ in biochar against microbial decomposition due to the increased condensation in aromatic $\mathrm{C}$.

5. Following surface oxidation of biochars, the potential for hydrophilic interactions of biochars with a range of soil organic and inorganic compounds increases. This is more significant in high mineral ash biochars (Lima and Marshall 2005). Greater reactivity of biochars with mineral matter could further promote physical protection of biochar and, thus, long-term stability (Brodowski et al. 2006).

6. Once roots and root hairs interact with the biochars, a much wider range of reactions can occur, through the uptake of nutrients, and the release of root exudates, which enhances both complexation reactions and microbial activity in the rhizosphere.

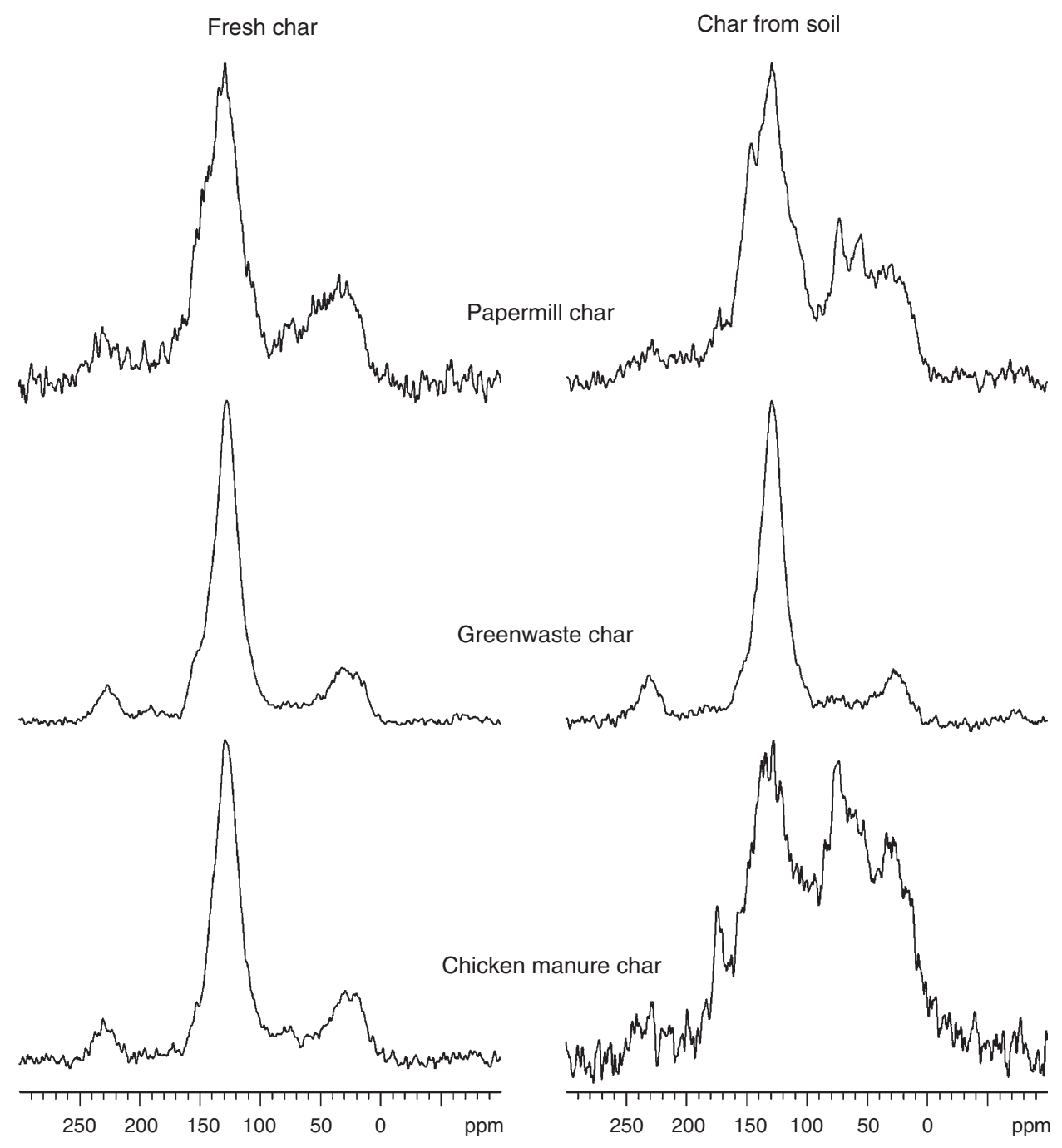

Fig. 9. Solid-state ${ }^{13} \mathrm{C} C P-N M R$ spectra of fresh biochars and 1-year weathered biochars. 


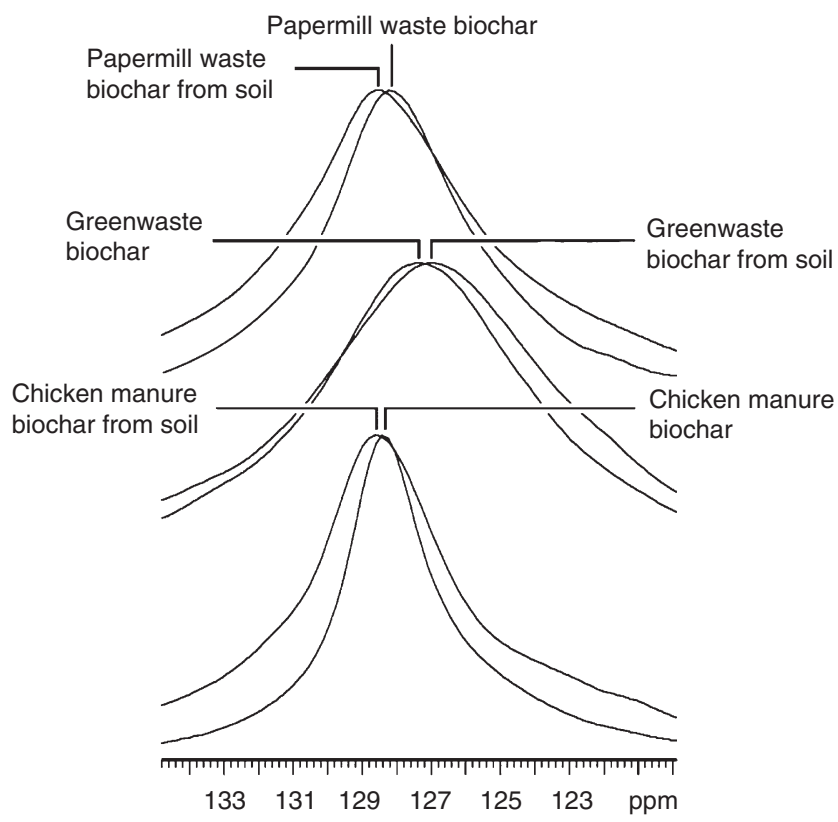

Fig. 10. Expansion of the aromatic region of the solid-state ${ }^{13} \mathrm{C}$ DP-NMR spectra of ${ }^{13} \mathrm{C}_{6}$-benzene sorbed to fresh biochars and 1 -year weathered biochars.

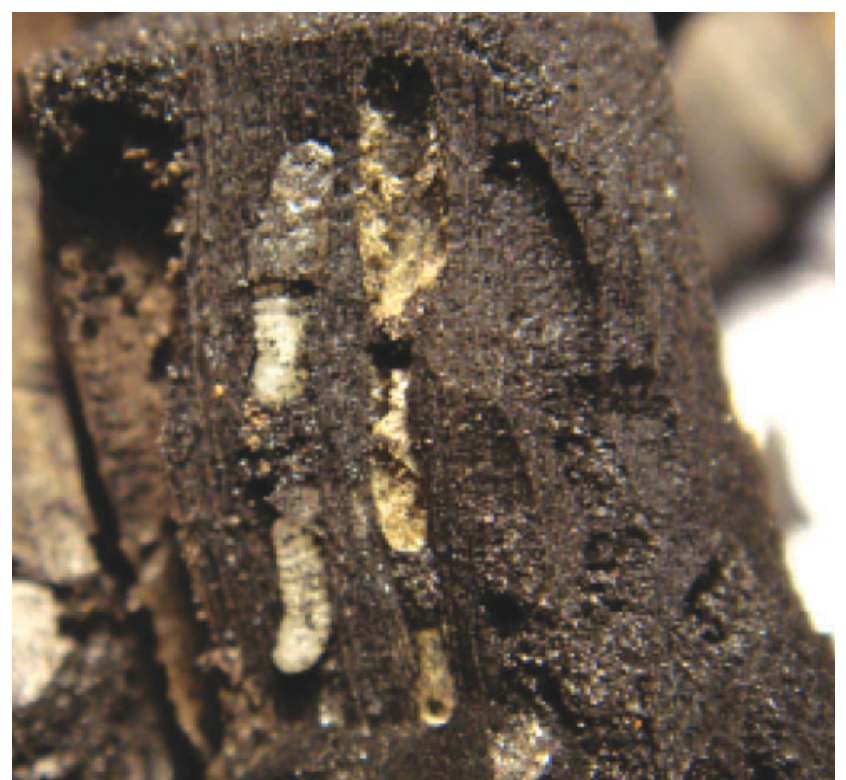

Fig. 11. Optical image showing larvae and casings inside a wood biochar. (Source: N. Foidl.)

Micropores
$\begin{aligned} & \text { Biochar surfaces } \\ & \text { lowly degrading } \\ & \text { via biotic and } \\ & \text { abiotic processes } \\ & \text { releasing organics } \\ & \text { and minerals }\end{aligned}$

Fig. 12. Schematic diagram of the possible phases on the surface of aged biochar.

Figure 12 summarises the reactions that can take place in and on the surfaces of biochar. The data obtained from microscopic and spectroscopic examination of the surfaces have been used to posit the possible mineral and organic structures that can occur during ageing of biochar. Formation of micropores, mesopores, and macropores has been identified between and within the different organo-mineral phases. As more data are obtained from detailed examination of aged biochars of known properties, this model will be refined. Greater understanding of these interactions will permit more accurate estimation of long-term stability and therefore climate change mitigation benefit from application of biochars.

\section{Acknowledgments}

S.J. is very grateful for the support of VenEarth LLC and his colleagues at Anthroterra Pty. M.C.A. is very grateful for financial support from the 
Ministry of Agriculture and Forestry of New Zealand. We acknowledge Professor Felipe Macías, from the Universidade de Santiago de Compostela, for his assistance in producing Fig. 3. The authors also thank the anonymous reviewers for their valuable suggestions.

\section{References}

Amonette JE, Joseph S (2009) Physical properties of biochar. In 'Biochar for environmental management. Science and technology'. (Eds J Lehmann, S Joseph) pp. 33-53. (Earthscan: London)

Amonette J, Kim J, Russell C, Hendricks M, Bashore C, Rieck B (2006) Soil charcoal-a potential humification catalyst. In 'ASA-CSSA-SSSA International Annual Meetings'. 12-16 November 2006. (ASA/CSSA/ SSSA: Madison, WI)

Antal MJ Jr, Grønli M (2003) The art, science, and technology of charcoal production. Industrial \& Engineering Chemistry Research 42, 1619-1640. doi:10.1021/ie0207919

Arvieu J-C, Leprince F, Plassard C (2003) Release of oxalate and protons by ectomycrorrhizal fungi in response to P-deficiency and calcium carbonate in nutrient solution. Annals of Forest Science 60, 815-821. doi:10.1051/forest:2003076

Bartlett RJ (1999) Characterizing soil redox behavior. In 'Soil physical chemistry'. 2nd edn (Ed. DL Sparks) pp. 371-395. (CRC Press: Boca Raton, FL)

Berglund I, DeLuca TH, Zackrisson O (2004) Activated carbon amendments to soils alters nitrification rates in Scots pine forests. Soil Biology \& Biochemistry 36, 2067-2073. doi:10.1016/j.soilbio.2004. 06.005

Blackwell P, Riethmuller G, Collins M (2009) Biochar application to soil. In 'Biochar for environmental management. Science and technology'. (Eds J Lehmann, S Joseph) pp. 207-226. (Earthscan: London)

Boehm HP (2001) Carbon surface chemistry. In 'Graphite and precursors'. (Ed. P Delhaes) pp. 141-178. (CRC: Amsterdam)

Boonchan S, Britz ML, Stanley GA (2000) Degradation and mineralization of high-molecular-weight polycyclic Aromatic Hydrocarbons by defined fungal-bacterial cocultures. Applied and Environmental Microbiology 66, 1007-1019. doi:10.1128/AEM.66.3.1007-1019.2000

Bridgwater A, Boocock DGB (2006) 'Science in thermal and chemical biomass conversion.' (CPL Press: Newbury, UK)

Brodowski S, John B, Flessa H, Amelung W (2006) Aggregate-occluded black carbon in soil. European Journal of Soil Science 57(4), 539-546. doi:10.1111/j.1365-2389.2006.00807.x

Brookins D (1988) 'Eh-pH diagrams for geochemistry.' (Springer-Verlag: Berlin)

Bruun S, Jensen ES, Jensen LS (2008) Microbial mineralization and assimilation of black carbon: dependency on degree of thermal alteration. Organic Geochemistry 39, 839-845. doi:10.1016/ j.orggeochem.2008.04.020

Buurman P, Jongmans AG, Pi-Pujol MD (1998) Clay illuviation and mechanical clay infiltration - is there a difference? Quaternary International 51-52, 66-69. doi:10.1016/S1040-6182(98)90225-7

Chan KY, Van Zwieten L, Meszaros I, Downie A, Joseph S (2008) Using poultry litter biochars as soil amendments. Australian Journal of Soil Research 46, 437-444. doi:10.1071/SR08036

Chan KY, Xu K (2009) Biochar: nutrient properties and their enhancement. In 'Biochar for environmental management. Science and technology'. (Eds J Lehmann, S Joseph) pp. 13-323. (Earthscan: London)

Cheng C-H, Lehmann J (2009) Ageing of black carbon along a temperature gradient. Chemosphere 75, 1021-1027. doi:10.1016/j.chemosphere. 2009.01.045

Cheng C-H, Lehmann J, Engelhard MH (2008) Natural oxidation of black carbon in soils: changes in molecular form and surface charge along a climosequence. Geochimica et Cosmochimica Acta 72, 1598-1610. doi:10.1016/j.gca.2008.01.010
Cheng C-H, Lehmann J, Thies JE, Burton SD, Engelhard MH (2006) Oxidation of black carbon by biotic and abiotic processes. Organic Geochemistry 37, 1477-1488. doi:10.1016/j.orggeochem.2006.06.022

Chesworth W (2004) Redox, soils, and carbon sequestration. Edafología 11, $37-43$.

Chia CH, Munroe P, Joseph S, Lin Y (2010) Microscopic characterisation of synthetic Terra Preta. Australian Journal of Soil Research 48, 593-605.

Cohen-Ofri I, Popovitz-Biro R, Weiner S (2007) Structural characterization of modern and fossilized charcoal produced in natural fires as determined by using electron energy loss spectroscopy. Chemistry - A European Journal 13, 2306-2310. doi:10.1002/chem.200600920

Contescu A, Vass M, Contescu C, Putyera K, Schwarz JA (1998) Acid buffering capacity of basic carbons revealed by their continuous pK distribution. Carbon 36(3), 247-258. doi:10.1016/S0008-6223(97) 00168-1

De Luca TH, MacKenzie MD, Gundale MJ (2009) Biochar effects on soil nutrient transformations. In 'Biochar for environmental management. Science and technology'. (Eds J Lehmann, S Joseph) pp. 251-270. (Earthscan: London)

Dias BO, Silva CA, Higashikawa FS, Roig A, Sanchez-Monedero A (2010) Use of biochar as bulking agent for the composting of poultry manure: effect on organic matter degradationand humification. Bioresource Technology 101, 1239-1246. doi:10.1016/j.biortech.2009.09.024

Dixon K (1998) Smoke germination of Australian plants. RIRDC Report 98/108, KPW-1A. RIRDC, Canberra, ACT.

Downie A, Crosky A, Munroe P (2009) Physical properties of biochar. In 'Biochar for environmental management. Science and technology'. (Eds J Lehmann, S Joseph) pp. 13-32. (Earthscan: London)

Eckmeier E, Gerlach R, Skjemstad JO, Ehrmann O, Schmidt MWI (2007) Minor changes in soil organic carbon and charcoal concentrations detected in a temperate deciduous forest a year after an experimental slash-and-burn. Biogeosciences 4(3), 377-383. doi:10.5194/bg-4-3772007

Feng J-W, Zheng S, Maciel GE (2004) EPR investigations of the effects of inorganic additives on the charring and char/air interactions of cellulose. Energy \& Fuels 18(4), 1049-1065. doi:10.1021/ef030151y

Gaskin J, Steiner C, Harris K, Das K, Bibens B (2008) Effect of lowtemperature pyrolysis conditions on biochar for agricultural use. Transactions of the ASABE 51(6), 2061-2069.

Hammes K, Schmidt MWI (2009) Changes of biochar in soil. In 'Biochar for environmental management. Science and technology'. (Eds J Lehmann, S Joseph) pp. 169-178. (Earthscan: London)

Hillel D (2004) 'Introduction to soil physics.' (Elsevier India Pty Ltd: New Delhi)

Hilscher A, Heister K, Siewert C, Knicker K (2009) Mineralization and structural changes during the initial phases of microbial degradation of pyrogenic plant residues in soil. Organic Geochemistry 40, 332-342. doi:10.1016/j.orggeochem.2008.12.004

Hockaday W, Grannas AM, Kim S, Hatcher PG (2007) The transformation and mobility of charcoal in a fire-impacted watershed. Geochimica et Cosmochimica Acta 71, 3432-3445. doi:10.1016/j.gca.2007.02.023

Hockaday WC (2006) The organic geochemistry of charcoal black carbon in the soils of the University of Michigan Biological Station. PhD Thesis, Ohio State University, Columbus, $\mathrm{OH}$.

Hofrichter M, Ziegenhagen D, Sorge S, Ullrich R, Bublitz F, Fritsche W (1999) Degradation of lignite (low-rank coal) by ligninolytic basidiomycetes and their manganese peroxidase system. Applied Microbiology and Biotechnology 52, 78-84. doi:10.1007/ s002530051490

Ishihara S (1996) Recent trend of advanced carbon materials from wood charcoals. Mokuzai Gakkai Shi 42, 717-723.

Keiluweit M, Kleber M (2009) Molecular-level interactions in soils and sediments: the role of aromatic $\pi$-systems. Environmental Science \& Technology 43(10), 3421-3429. doi:10.1021/es8033044 
Keiluweit M, Nico PS, Johnson MG, Kleber M (2010) Dynamic molecular structure of plant biomass-derived black carbon (biochar). Environmental Science \& Technology 44, 1247-1253.

Kennedy I (2001) 'Action in ecosystems: biothermodynamics for sustainability.' (Research Studies Press: Baldock, UK)

Kleber M, Sollins P, Sutton R (2007) A conceptual model of organo-mineral interactions in soils: self-assembly of organic molecular fragments into zonal structures on mineral surfaces. Biogeochemistry 85, 9-24. doi:10.1007/s10533-007-9103-5

Knicker H, Almendros G, González-Vila FJ, Martin F, Lüdemann HD (1996) ${ }^{13} \mathrm{C}$ - and ${ }^{15} \mathrm{~N}-\mathrm{NMR}$ spectroscopic examination of the transformation of organic nitrogen in plant biomass during thermal treatment. Soil Biology \& Biochemistry 28(8), 1053-1060. doi:10.1016/0038-0717(96)00078-8

Kögel-Knabner I, Guggenberger G, Kleber M, Kandeler E, Kalbitz K, Scheu S, Eusterhues K, Leinweber P (2008) Organo-mineral associations in temperate soils: integrating biology, mineralogy, and organic matter chemistry. Journal of Plant Nutrition and Soil Science 171(1), 61-82. doi:10.1002/jpln.200700048

Kuzyakov Y, Subbotina I, Chen H, Bogomolova I, Xu X (2009) Black carbon decomposition and incorporation into soil microbial biomass estimated by ${ }^{14} \mathrm{C}$ labeling. Soil Biology \& Biochemistry 41(2), 210-219. doi:10.1016/j.soilbio.2008.10.016

Kwon S, Pignatello J (2005) Effect of natural organic substances on the surface and adsorptive properties of environmental black carbon (char): pseudo pore blockage by model lipid components and its implications for $\mathrm{N}_{2}$-probed surface properties of natural sorbents. Environmental Science \& Technology 39, 7932-7939. doi:10.1021/ es050976h

Lagaly G (1984) Clay-organic interactions. Royal Society of London Philosophical Transactions Series A 311, 315-332. doi:10.1098/ rsta.1984.0031

Lasaga AC (1998) 'Kinetic theory in the earth sciences.' (Princeton University Press: Princeton, NJ)

Lehmann J, Joseph S (2009) 'Biochar for environmental management Science and technology.' (Earthscan: London)

Lehmann J, Liang B, Solomon D, Lerotic M, Luizão F, Kinyangi F, Schäfer T, Wirick S, Jacobsen C (2005) Near-edge X-ray absorption fine structure (NEXAFS) spectroscopy for mapping nano-scale distribution of organic carbon. Global Biogeochemical Cycles 19, GB1013. doi:10.1029/2004GB002435

Leon y Leon CA, Solar JM, Calemma V, Radovic LR (1992) Evidence for the protonation of basal plane sites on carbon. Carbon 30(5), 797-811. doi:10.1016/0008-6223(92)90164-R

Liang B, Lehmann J, Sohi SP, Thies JE, O’Niell B, Trujillo L, Gaunt J, Solomon D, Grossman J, Neves EG, Luizão FJ (2010) Black carbon affects the cycling of non-black carbon in soil. Organic Geochemistry 41, 206-213. doi:10.1016/j.orggeochem.2009.09.007

Light ME, Daws MI, Van Staden J (2009) Smoke-derived butenolide: towards understanding its biological effects. South African Journal of Botany 75, 1-7. doi:10.1016/j.sajb.2008.10.004

Lima IM, Marshall WE (2005) Granular activated carbons from broiler manure: physical, chemical and adsorptive properties. Bioresource Technology 96, 699-706. doi:10.1016/j.biortech.2004.06.021

Macías F (2004) Sumideros de carbon para el forzamiento climatic antropoceno: una vision de alternativas de actuacion desde la ciencia del suelo. Edafologia 11, 7-25.

Macías F, Camps Arbestain M (2010) Soil carbon sequestration in a global environment. Mitigation and Adaptation Strategies for Global Change, in press. doi:10.1007/s11027-010-9231-4

MacKenzie MD, DeLuca TH (2006) Charcoal and shrubs modify soil processes in ponderosa pine forests of western Montana. Plant and Soil 287, 257-266. doi:10.1007/s11104-006-9074-7
Major J, Lehmann J, Rondon M, Goodale C (2009a) Fate of soil-applied black carbon: downward migration, leaching and soil respiration. Global Change Biology 16, 1366-1379. doi:10.1111/j.1365-2486.2009.02044.x

Major J, Steiner C, Downie A, Lehmann J (2009b) Biochar effects on nutrient leaching. In 'Biochar for environmental management. Science and technology'. (Eds J Lehmann, S Joseph) pp. 271-288. (Earthscan: London)

Marley NA, Bennett P, Janecky DR, Gaffney JS (1989) Spectroscopic evidence for organic diacid complexation with dissolved silica in aqueous systems-I. Oxalic acid. Organic Geochemistry 14(5), 525-528. doi:10.1016/0146-6380(89)90032-6

Marschner B (1999) 'Mineral nutrition of higher plants.' 2nd edn (Academic Press: London)

Matusik J, Gawel A, Bielanska E, Osuch W, Bahranowski K (2009) The effect of structural order on nanotubes derived from kaolin-group minerals. Clays and Clay Minerals 57, 452-464. doi:10.1346/ CCMN.2009.0570406

McBeath AV, Smernik RJ (2009) Variation in the degree of aromatic condensation of chars. Organic Geochemistry 40, 1161-1168. doi:10.1016/j.orggeochem.2009.09.006

McClellan AT, Deenik J, Uehara G, Antal M (2007) Effects of flash carbonized macadamia nutshell charcoal on plant growth and soil chemical properties. In 'Proceedings American Society of Agronomy Conference'. Abstracts. 3-7 November, New Orleans, LA. (ASA: Madison, WI)

Michael G (2001) The control of root hair formation: suggested mechanisms. Journal of Plant Nutrition and Soil Science 164(2), 111-119. doi:10.1002/1522-2624(200104)164:2<111::AID-JPLN111> 3.0.CO;2-A

Mizuta K, Matsumoto T, Hatate Y, Nishihara K, Nakanishi T (2004) Removal of nitrate nitrogen from drinking water using bamboo powder charcoal. Bioresource Technology 95, 255-257. doi:10.1016/ j.biortech.2004.02.015

Montes-Morán MA, Suárez D, Menéndez JA, Fuente E (2004) On the nature of basic sites on carbon surfaces: an overview. Carbon 42(7), 1219-1225. doi:10.1016/j.carbon.2004.01.023

Nguyen B, Lehmann J (2009) Black carbon decomposition under varying water regimes. Organic Geochemistry 40, 846-853. doi:10.1016/ j.orggeochem.2009.05.004

Nguyen B, Lehmann J, Hockaday WC, Joseph S, Masiello C (2010) Temperature sensitivity of black carbon decomposition and oxidation. Environmental Science \& Technology 44, 3324-3331. doi:10.1021/ es903016y

Nocentini C, Certini G, Knicker H, Francioso O, Rumpel C (2010) Nature and reactivity of charcoal produced and added to soil during wildfire are particle-dependent. Organic Geochemistry 42, 682-689. doi:10.1016/ j.orggeochem.2010.03.010

Ogawa M (1994) Symbiosis of people and nature in the tropics. Farming Japan 28, 10-34.

Painter TJ (2001) Carbohydrate polymers in food preservation: an integrated view of the Maillard reaction with special reference to discoveries of preserved foods in Sphagnum dominated peat bogs. Carbohydrate Polymers 36, 335-347. doi:10.1016/S0144-8617(97)00258-0

Pignatello JJ, Kwon S, Lu Y (2006) Effect of natural organic substances on the surface and adsorptive properties of environmental black carbon (char): attenuation of surface activity by humic and fulvic acids. Environmental Science \& Technology 40(24), 7757-7763. doi:10.1021/es061307m

Quaggiotti S, Ruperti B, Pizzeghello D, Francioso O, Tugnoli V, Nardi S (2004) Effect of low molecular size humic substances on nitrate uptake and expression of genes involved in nitrate transport in maize (Zea mays L.). Journal of Experimental Botany 55(398), 803-813. doi:10.1093/jxb/erh085 
Riedlinger J, Schrey S, Tarkka M, Hampp R, Kapur M, Fiedler H (2006) Auxofuran, a novel metabolite that stimulates the growth of fly agaric, is produced by the mycorrhiza helper bacterium Streptomyces strain $\mathrm{AcH}$ 505. Applied and Environmental Microbiology 72(5), 3550-3557. doi:10.1128/AEM.72.5.3550-3557.2006

Shinogi Y, Yoshida H, Koizumi T, Yamaoka M, Saito T (2003) Basic characteristics of low-temperature carbon products from waste sludge. Advances in Environmental Research 7(3), 661-665. doi:10.1016/ S1093-0191(02)00040-0

Singh BP, Cowie AL (2008) A novel approach, using ${ }^{13} \mathrm{C}$ natural abundance, for measuring decomposition of biochars in soil. In 'Carbon and Nutrient Management in Agriculture, Fertilizer and Lime Research Centre Workshop Proceedings'. (Eds LD Currie, LJ Yates) pp. 549. (Massey University: Palmerston North, New Zealand)

Singh B, Singh BP, Cowie AL (2010) Characterisation and evaluation of biochars for their application as a soil amendment. Australian Journal of Soil Research 48, 516-525.

Smernik R (2009) Biochar and sorption of organic compounds. In 'Biochar for environmental management. Science and technology'. (Eds J Lehmann, S Joseph) pp. 289-296. (Earthscan: London)

Spokas K, Reicosky D (2009) Impacts of sixteen different biochars on soil greenhouse gas production. Annals of Environmental Science 3, 179-193.

Steinbeiss S, Gleixner G, Antonietti M (2009) Effect of biochar amendment on soil carbon balance and soil microbial activity. Soil Biology \& Biochemistry 41, 1301-1310. doi:10.1016/j.soilbio.2009.03.016

Steiner C, Teixeira W, Lehmann J, Nehls T, Vasconcelos de Mace ${ }^{\wedge}$ do J, Blum W, Zech W (2007) Long term effects of manure, charcoal and mineral fertilization on crop production and fertility on a highly weathered Central Amazonian upland soil. Plant and Soil 291, 275-290. doi:10.1007/s11104-007-9193-9

Tarkka MT, Lehr NA, Hampp R, Schrey SD (2008) Plant behavior upon contact with streptomycetes. Plant Signaling \& Behavior 3(11), 917.

Thies E, Rilling MC (2009) Characteristics of biochar: biological properties. In 'Biochar for environmental management. Science and technology'. (Eds J Lehmann, S Joseph) (Earthscan: London)

Van Zwieten L, Kimber S, Morris S, Chan KY, Downie A, Rust J, Joseph S, Cowie A (2010) Effects of biochar from slow pyrolysis of papermill waste on agronomic performance and soil fertility. Plant and Soil 327, 235-246. doi:10.1007/s11104-009-0050-x
Violante A, Gianfreda L (2000) The role of biomolecules in the formation and reactivity towards nutrient and organics of variable charge minerals and organominerals. In 'Soil biochemistry'. (Eds J Bollag, G Stotzky) (Marcel Dekker: New York)

Wardle DA, Zackrisson O, Nilsson M-C (1998) The charcoal effect in boreal forests: mechanisms and ecological consequences. Oecologia 115, 419-426. doi:10.1007/s004420050536

Wornat MJ, Hurt RH, Yang NYC (1995) Structural and compositional transformations of biomass chars during combustion. Combustion and Flame 100, 131-143. doi:10.1016/0010-2180(94)00055-W

Yan F, Schubert S, Mengel K (1996) Soil pH increase due to biological decarboxylation of organic anions. Soil Biology \& Biochemistry 28, 617-624. doi:10.1016/0038-0717(95)00180-8

Yao FX, Camps Arbestain M, Virgel S, Blanco F, Arostegui J, Maciá-Agulló JA, Macías F (2010) Simulated geochemical weathering of a mineral ashrich biochar in a modified Soxhlet reactor. Chemosphere 80, 724-732. doi:10.1016/j.chemosphere.2010.05.026

Yariv S, Cross H (2002) 'Organo-clay complexes and interactions.' (Marcel Dekker: New York)

Yoshizawa S, Tanaka S, Ohata M (2007) Proliferation effect of aerobic micro-organisms during composting of rice bran by addition of biomass charcoal. In 'Proceedings of the International Agrichar Conference'. Terrigal, NSW. p.26. International Agrichar Initiative: www.iaiconference.org

Zackrisson O, Nilsson M-C, Wardle DA (1996) Key ecological function of charcoal from wildfire in the Boreal forest. Oikos 77, 10-19. doi: $10.2307 / 3545580$

Zhu D, Kwon S, Pignatello J (2005) Adsorption of single-ring organic compounds to woody charcoals prepared under different thermochemical conditions. Environmental Science \& Technology 39, 3990-3998. doi:10.1021/es050129e

Manuscript received 5 January 2010, accepted 24 May 2010 